\title{
In Vitro Modulation of Human Intestinal Microbiota by Mannoligosaccharides Synthesized from Amorphophallus muelleri Glucomannan
}

\author{
ACHMAD DINOTO $^{1 *}$, CORY CORAZON WATUMLAWAR ${ }^{2}$, AND YOPI $^{3}$ \\ ${ }^{\prime}$ Research Center for Biology, Indonesian Institute of Sciences (LIPI). Jalan Raya Jakarta-Bogor KM 46, \\ Cibinong 16911, Jawa Barat, Indonesia; \\ ${ }^{2}$ Sekolah Tinggi Teknologi Industri dan Farmasi (STTIF), Jalan Kumbang 23, \\ Bogor 16151, Jawa Barat, Indonesia; \\ ${ }^{3}$ Research Center for Biotechnology, Indonesian Institute of Sciences (LIPI), \\ Jalan Raya Jakarta-Bogor KM 46, Cibinong 16911,Jawa Barat, Indonesia
}

The corms of Amorphophallus muelleri Blume contain a large amount of glucomannan, a kind of polysaccharide that are commonly consumed by people as gelly foods. In order to improve the beneficial properties of glucomannan, we previously have established the enzymatic process to produce the mannoligosaccharides from flour of glucomannan using microbial mannanase. The effects of mannoligosaccharides on the growth modulation of human intestinal microbiota were investigated in this study. A set of in vitro single batch culture experiment was conducted to study the effect of mannooligosaccharides on human-origin Lactobacillus fermentum AA0014 and Lactobacillus plantarum FU0811. A modified MRS medium containing $10 \%(\mathrm{w} / \mathrm{v})$ sucrose, glucomannan, and mannoligosaccharide was used instead of glucose as carbon source. The results showed the highest growth rate $\left(0.13 \mathrm{~h}^{-1}\right)$ with both $L$. fermentum AA0014 and $L$. plantarum FU0811 in the presence of mannooligosaccharides. We confirmed this result by a similar in vitro experiment using human fecal samples of six healthy adults as innocula and analyzed the microbial population by fluorescence in situ hybridization (FISH). Lactobacilli were proliferated higher in the presence of mannoligosaccharide than other carbon sources, yielding the microbial proportion as much of $10.9 \%$ of total microbiota. Overall, this study demonstrated the potential use of mannoligosaccharides synthesized from $A$. muelleri glucomannan as prebiotic candidate of modulating the beneficial human intestinal microbiota.

Key words: Amorphophallus muelleri, growth modulation, human intestinal, mannoligosaccharides, microbiota, prebiotic

Umbi Amorphophallus muelleri Blume mengandung sejumlah tinggi senyawa glukomannan, yaitu sejenis polisakarida yang umum dikonsumsi oleh masyarakat sebagai produk pangan jeli. Untuk meningkatkan manfaat glukomannan, penelitian sebelumnya telah dilakukan untuk mendapatkan produk mannooligosakarida hasil reaksi enzimatik tepung glukomannan menggunakan enzim mannanase. Pada penelitian ini, mannooligosakarida hasil reaksi enzimatik dikaji pengaruhnya terhadap modulasi pertumbuhan mikrobiota saluran cerna manusia. Percobaan kultur curah telah dilakukan untuk memahami efek stimulasi mannooligosakarida terhadap bakteri Lactobacillus fermentum AA0014 and Lactobacillus plantarum FU0811 asal manusia. Medium MRS modifikasi yang mengandung $10 \%(\mathrm{~b} / \mathrm{v})$ sukrosa, glukomannan dan mannoligosakarida digunakan sebagai sumber karbon menggantikan glukosa. Hasil menunjukkan bahwa kecepatan pertumbuhan tertinggi $\left(0.13 \mathrm{jam}^{-1}\right)$ ditunjukkan oleh L. fermentum AA0014 and L. plantarum FU0811 pada substrat mannooligosakarida. Konfirmasi dilakukan dengan percobaan in vitro serupa, namun menggunakan sampel feses manusia asal enam orang dewasa sehat sebagai inokulum mikrobiota usus. Populasi mikrobiota dianalisis dengan fluorescence in situ hybridization (FISH) dan hasil menunjukkan bahwa kelompok lactobacilli dapat digandakan populasinya lebih tinggi dengan substrat mannooligosakarida dibandingkan sumber karbon lainnya, yaitu mencapai $10.9 \%$ dari total mikrobiota. Secara umum, penelitian ini menunjukkan potensi penggunaan mannooligosakarida yang disintesis dari glukomannan A. muelleri sebagai kandidat prebiotik yang berperan dalam memodulasi pertumbuhan mikrobiota saluran cerna manusia yang menguntungkan.

Kata kunci: Amorphophallus muelleri, mannoligosakarida, manusia, modulasi pertumbuhan, mikrobiota saluran cerna, prebiotik

Porang (Amorphophallus muelleri Blume) is a robust herbacous plant commonly found in Asia that produces the potential corms, large globulose depressed tubber. The corms contain carbohydrate in

*Corresponding author; Phone/Fax: +62-21-8765066/+6221-8765062,Email: achmaddinoto@yahoo.com which mostly are in the form of mannan (Kay 1973). Depending on the cultivar, the glucomannan contents in the corms of $A$. konjac are 29 to $59 \%$ of total dry weight (Chua et al. 2010). In several countries, the corms were eaten as vegetable and also used for industrial purposes such as the source of flour and 
mannose (Kay 1973). The corms of A. konjac has been used as food and food additives in China and Japan for more than 1000 years. In addition, the potential use of glucomannan derived from konjac tuber have been studied for the application in pharmaceuticals, cosmetics, coating materials, and emulsifier (AlosoSande et al. 2009; Chua et al. 2010; Zhang et al. 2005). As food compounds, the glucomannan of A. konjac have been investigated previously for anti-obesity, antihyperglycemic and hypercholesterolemia, antiinflammatory, and laxative activities as well as prebiotic properties (Chen et al. 2006; Chua et al. 2010). Glucomannan was considered to have diet therapy in primary prevention in high risk hypercholesterolemic children (Martino et al. 2005).

There is increasing interest in the development of mannan-based prebiotics. The mannanase-producing bacteria were applied to produce prebiotic mannooligosaccharides, using copra as raw materials (Titapoka et al. 2008). Basically glucomannan can be hydrolized to produce mannoligosaccharides. In previous study, we have succesfully established the processing methods for synthesizing the mannoligosaccharides from glucomannan by using the mannanase of actinomycetes isolates (Yopi et al. unpublished data). Oligosaccharides are important to stimulate efectively the beneficial microbiota in gastrointestinal tract, especially bifidobacteria in human and animal (Dinoto et al. 2006a; Dinoto et al. 2006b). Lactobacilli was also increased in rat cecal after administering raffinose and encapsulated bifidobacteria (Dinoto et al. 2006b). Similary, modulation of beneficial microbes by fructooligosaccharides and galactooligosaccharides were also reported (Rycroft et al. 2001). Several oligosaccharides have been investigated intensively in human subject or using human feces as innoculum, including fructooligosaccharides, galactooligosaccharides, maltooligosaccharides, and xylooligosaccharides (Rossi et al. 2005; Rycroft et al. 2001; Tuohy et al. 2005).

The role of mannoligosaccharides in modulation of human intestinal microbiota is not completely understood. Although some information is available on the effects of feeding mannoligosaccharides in the health status of human and animal, there is a limited information about the potential uses A. muelleri corms-based mannoligosaccharides for modulating gut microbial population. In this study, we investigated whether mannoligosaccharides influence the microbial population and metabolite profiles in the static batch culture of human intestinal microbiota.

\section{MATERIALS AND METHODS}

Strains and Material Preparation. Bacterial strains used in this study are Lactobacillus fermentum strain AA0014 and Lactobacillus plantarum strain FU0811. Those strains are human-origin and belonging to the collection of Research Center for Biology, Indonesian Institute of Sciences, Indonesia. In this study we used glucomannan flour of A. muelleri (provided by PT. Ambico, Indonesia). Mannoligosaccharides sample used in this study was synthesized by the reaction of glucomannan flour and mannanase enzyme of Saccharopolyspora flava BTCC ID040555, which was kindly provided by the collection of the Biotechnology Culture Collection, Research Center for Biotechnology, Indonesian Institute of Sciences. The liquid products of glucomannan and mannoligosaccharides used in the experiment were adjusted to final concentration of $10 \mathrm{~g}$ per liter medium.

Measurement of the Growth Rate. To determine the growth rate of representative probiotic candidate lactobacilli in several carbon sources, a seed culture for L. fermentum AA0014 and L. plantarum FU0811 growth experiments was grown overnight in MRS medium (de Man et al. 1960). At an optical density at $\mathrm{OD}_{600}=0.8$ of seed culture was transferred to the same MRS-based medium, but containing one of the following carbohydrates (10 g L $\left.\mathrm{L}^{-1}\right)$ : glucose (Merck), sucrose (Merck), glucomannan, and mannoligosaccharides. Bacterial growth was periodically monitored by determining the $\mathrm{OD}_{600}$ of the culture broth. All the cultures were incubated at $37{ }^{\circ} \mathrm{C}$ under anaerobic conditions using carbondioxide. Specific growth rates $(\mu)\left(\right.$ in $\left.^{-1}\right)$ were calculated during the logarithmic growth phase using the following equation: $\mu=\left(\operatorname{ln~xt}_{2}-\operatorname{lnxt}_{1}\right) /\left(\mathrm{t}_{2}\right.$ $-t_{1}$ ), where $\mathrm{xt}_{2}$ and $\mathrm{xt}_{1}$ are the $\mathrm{OD}_{600}$ values at times $\mathrm{t}_{2}$ and $\mathrm{t}_{1}$, respectively.

Static Batch Culture Fermentations. The experiment was conducted as described by OlanoMartin et al. (2000). In autoclaved $50 \mathrm{~mL}$ serum bottles containing each substrate $(0.5 \mathrm{~g})$, aliquot of $45 \mathrm{~mL}$ autoclaved nutrient medium was added by filter sterilization to each bottle. The basal medium contained ( $\mathrm{g} \mathrm{L}^{-1}$ ): peptone water, 2; yeast extract, 2; $\mathrm{NaCl}, 0.1$; $\mathrm{K}_{2} \mathrm{HPO}_{4}, 0.04 ; \mathrm{KH}_{2} \mathrm{PO}_{4}, 0.04 ; \mathrm{MgSO}_{4} .7 \mathrm{H}_{2} \mathrm{O}, 0.01$; $\mathrm{CaCl}_{2} \cdot 6 \mathrm{H}_{2} \mathrm{O}, 0.01 ; \mathrm{NaHCO}_{3}, 2$; hemin (dissolved in a few drops of $\left.1 \mathrm{~mol} \mathrm{l}^{-1} \mathrm{NaOH}\right), 0.05$; cysteine. $\mathrm{HCl}, 0.5$; bile salts, 0.5; Tween 80,2 and $10 \mu \mathrm{L}$ vitamin $\mathrm{K}_{1}$. The medium was adjusted to neutral ( $\mathrm{pH} 7.0$ ). using $1 \mathrm{~mol} \mathrm{~L}^{-1}$ $\mathrm{HCl}$. Before innoculation, the bottles containing medium were placed inside anaerobic jar (Merck) with 
supplementation of Anaerocult (Merck) at $37{ }^{\circ} \mathrm{C}$ overnight to prereduce the media. A $10 \%(\mathrm{w} / \mathrm{v})$ fecal slurry was prepared using fresh feces from six healthy donors (who had not taken antibiotics for 3 months beforehand) and prereduced $0.1 \mathrm{~mol} \mathrm{~L}^{-1}$ phosphate buffer (pH 7.0). Fecal slurry was mixed in a sterilized tube for $2 \mathrm{~min}$. In each serum bottle, $5 \mathrm{~mL}$ of the slurry were inoculated, mixed and capped. Samples were removed from the fermenters at $24 \mathrm{~h}$ fermentation for enumeration of microbiota, and measurement of SCFA. The fermentation experiments were performed in triplicate for each.

Fluorescence in situ Hybridization Analysis. The samples $(100 \mu \mathrm{L})$ from the static batch culture at $24 \mathrm{~h}$ fermentation were removed and washed with phosphate buffered saline (PBS) $(130 \mathrm{mM} \mathrm{NaCl}, 10$ $\mathrm{mM}$ sodium phosphate buffer; $\mathrm{pH} 7.2$ ) at $9000 \times \mathrm{g} 4{ }^{\circ} \mathrm{C}$ for $2 \mathrm{~min}$. The washed samples were fixed in $4 \%(\mathrm{w} / \mathrm{v})$ paraformaldehyde in PBS (pH 7.2) for $24 \mathrm{~h}$. Fixed samples were washed once in PBS and stored in a known volume of $50 \%(\mathrm{v} / \mathrm{v})$ ethanol-PBS at $-20{ }^{\circ} \mathrm{C}$ until use. FISH analysis was conducted as described by Dinoto et al. (2006b). Aliquots ( $3 \mu \mathrm{L})$ of fixed cells were applied to Teflon printed glass slides (ADCELL; 12 wells; diameter, $5 \mathrm{~mm}$; Erie Scientific Company, Portsmouth, N.H.), and air dried. The cells were then dehydrated with a series of solutions containing $50 \%$, $80 \%$, and $99.5 \%$ ethanol (3 $\mathrm{min}$ for each concentration). The cells fixed on the glass slides were hybridized by addition of $8 \mu \mathrm{L}$ of hybridization buffer $(0.9 \mathrm{M} \mathrm{NaCl}, 0.01 \%$ sodium dodecyl sulfate, $20 \mathrm{mM}$ Tris- $\mathrm{HCl}, 20 \%$ deionized formamide; $\mathrm{pH}$ 7.2) with 1 $\mu \mathrm{L}$ of Cy3-labeled oligonucleotide probe (25 $\mathrm{ng} \mu \mathrm{L}^{-1}$; Tsukuba Oligo Service Co., Ltd., Tsukuba, Japan). The 16S rRNA-targeted oligonucleotide probes used for molecular analysis of Lactobacillus spp. (Lacb722, SG-Lacb-0722-a-A-25, YCACCGCTACACAT GRAG TTCCACT) (Sghir et al. 1999), Bifidobacterium spp. (Bif164m, S-G-Bif-0164-b-A-18, CATCCGGYATTA CCACCC) (Dinoto et al. 2006a), Clostridium coccoides-Eubacterium rectale group (Erec482, S-*Erec-0482-a-A-19, GCTTCTTAGTCA RGTACCG) (Franks et al. 1998), and Streptococcus spp. (Strc493, S-*-Strc-0493-a-A-19, GTTAGCCGTCCCTTTCTG G) (Franks et al. 1998). The slides were hybridized at 46 ${ }^{\circ} \mathrm{C}$ for $16 \mathrm{~h}$ in a moist chamber. After hybridization, the slides were rinsed with warm hybridization buffer at 48 ${ }^{\circ} \mathrm{C}$ and washed in prewarmed washing buffer $(225 \mathrm{mM}$ $\mathrm{NaCl}, 0.01 \%$ sodium dodecyl sulfate, $20 \mathrm{mMTris}-\mathrm{HCl}$; $\mathrm{pH}$ 7.2) for $20 \mathrm{~min}$ at $48{ }^{\circ} \mathrm{C}$. The washed slides were stained with a DAPI (4',6-diamidino-2-phenylindole dihydrochloride $n$-hydrate) solution for $5 \mathrm{~min}$ at room temperature to stain the chromosomes as a control signal. The slides were washed with distilled water for 5 min at room temperature and air dried in the dark. The dried slides were mounted with Vectashield (Vector Laboratories Inc., Burlingame, Calif.) and examined with an Nikon OPTIHOT-2 (Nikon Corporation, Tokyo, Japan) equipped with a Nikon Digital Camera. The DAPI and Cy3 signals were captured in pairs of 10 random microscopic fields (about 500 cells per microscopic field). Hybridization images were manually counted and were colorized when necessary using Adobe Photoshop 7.0 (Adobe Systems Incorporated, San Jose, Calif.). Specific signals from the probes were expressed as average percentages of the total cells visualized by DAPI signals in the same microscopic field.

Short-chain Fatty Acid Analysis and pH Measurement. The measurement of short chain fatty acid was carried out by taking samples from the bottles of the static batch culture at $24 \mathrm{~h}$ fermentation. Samples were centrifuged $(13000 \times \mathrm{g}$ for $30 \mathrm{~min})$ and filtered by $0.2 \mu \mathrm{m}$ syringe to remove particulate material. Ten microliter samples were then injected onto an HPLC system (Model Water 1350T, Biorad, UK). The column used in this analysis was an ion-exclusion Aminex HPX-87H (Bio-Rad) which maintained at $35^{\circ} \mathrm{C}$ with a column heater and the pressure of $2071 \mathrm{psi}$. The eluent, $0.008 \mathrm{~N}$ sulphuric acid in HPLC-grade water was pumped through the column at a flow rate of $1.0 \mathrm{~mL}$ $\mathrm{min}^{-1}$. Data from the RI detector were integrated and by using calibration curves, acetate, propionate, succinate, and lactate were quantified in the samples. The $\mathrm{pH}$ of suspension was determenided by using IQ120 miniLab $^{\mathrm{TM}} \mathrm{pH}$ meter (Hach Company, Loveland, CO).

Statistical Analysis. The data of total cell counts, microbial proportions, $\mathrm{pH}$, and SCFA concentrations for culture were analyzed statistically using SPSS software version 13.0 (SPSS, Inc., Chicago, IL). Bonferroni tests were performed for pair-wise multiple comparisons of the mean values for the glucose, sucrose, glucomannan, and mannoligosaccharides.

\section{RESULTS}

In this study, we determined the specific growth rate of selected L. plantarum FU0811 and L. fermentum AA0014 as representative human intestinal lactobacilli on the culture containing glucose, sucrose, glucomannan, and mannoligosaccharides as sole carbon source. Under this experimental condition, both 
L. plantarum and L. fermentum grew faster in the presence of mannoligosaccharides yielding the highest specific growth rate as much of $0.13 \mathrm{~h}^{-1}$ (Table 1 ). We observed that the growth of those strains became slower when they were cultured in the glucomannan medium. Interestingly, L. plantarum and L. fermentum have lower growth rates in the presence of glucose $(0.05$ and $0.04 \mathrm{~h}^{-1}$, respectively) as compared to sucrose medium $\left(0.09\right.$ and $\left.0.10 \mathrm{~h}^{-1}\right)$, respectively (Table 1$)$.

The cell morphology of intestinal microbiota in the batch culture inoculated with human fecal samples of six healthy adults were varied. Based on FISH analysis, we observed many cells were matched with oligonucleotide probe used in this study. The long-rod cells identified as lactobacilli under epifluorescence microscope were clearly distributed among other intestinal bacteria in batch culture (Fig 1). Since we did not monitored the population hour-by-hour, the $24 \mathrm{~h}$ observation could be used as representing impact of carbon source on human microbiota. The changes in selected bacterial populations with the carbon sources tested are presented in Table 2. Total cell counts of intestinal microbiota in glucose medium was about $9.43 \log _{10}$ cells $\mathrm{mL}^{-1}$ indicating that microbial cells in fecal slurry proliferated under experimental system. Population of microbes before $6 \mathrm{~h}$ fermentation was observed under $7 \log _{10}$ cells $\mathrm{mL}^{-1}$ and it was unsufficient for analysis of FISH. There is different cell number of microbiota when sucrose was used in this experiment (Table 2). With all of the carbon source studied, a large significant increase in numbers of lactobacilli was observed in mannoligosaccharides medium (10.9\%), whereas a relatively lower number was monitored in glucomannan medium (3.2\%) and sucrose medium (2.6\%). The population of lactobacilli in glucose medium was only $0.7 \%$ of total microbiota. The highest population of bifidobacteria was found in mannoligosaccharides medium (3.3\%) and we also confirmed that this group of bacteria was relatively low in sucrose and glucose media (lower than $0.1 \%$ of total microbiota). In contrast, the populations of Eubacterium/Clostridium showed a lower proportion in mannoligosaccharides medium than in sucrose medium or glucose medium (Table 2). Our data also showed no streptococci were detected in all tested carbon sources, indicating that this group of bacteria was absent or out of detection limit in FISH analysis $\left(<10^{7}\right.$ cells). Overall, this experimental system clearly demonstrated that the growth of human intestinal microbiota is much more stimulated by mannoligosaccharides.

There was a change in the $\mathrm{pH}$ during fermentation of carbon sources by intestinal microbiota of human origin. We observed that the $\mathrm{pH}$ change at the static batch culture of human fecal slurry during $24 \mathrm{~h}$ fermentation with various carbon sources used in this study is about 2-3 (Fig 2). In general, carbohydrate was rapidly metabolished by intestinal bacteria to produce organic acids. The occurences of nutrient metabolisms by intestinal microbiota could be simply recognized by the profile of short chain fatty acids (SCFA). SCFA are the products of microbial activities in the fermentations and only produced in appreciable levels in the presence of added carbohydrate. In this study, we observed that only lactate, acetate, and propionate were detected in all samples, whereas succinate was not detected. The

Table 1 The Specific growth rate $(\mu)$ of human-origin Lactobacillus fermentum AA0014 and Lactobacillus plantarum FU0811

\begin{tabular}{lc}
\hline & Specific growth rate $\left(\mathrm{h}^{-1}\right) \pm \mathrm{SD}^{*}$ \\
\hline Lactobacillus fermentum AA0014 & \\
Glucose & $0.04 \pm 0.01$ \\
Sucrose & $0.10 \pm 0.00$ \\
Glucomannan & $0.01 \pm 0.01$ \\
Mannoligosaccharides & $0.13 \pm 0.01$ \\
Lactobacillus plantarum FU0811 & \\
Glucose & $0.05 \pm 0.03$ \\
Sucrose & $0.09 \pm 0.00$ \\
Glucomannan & $0.02 \pm 0.02$ \\
Mannoligosaccharides & $0.13 \pm 0.01$ \\
\hline
\end{tabular}

*SD, standard deviation 


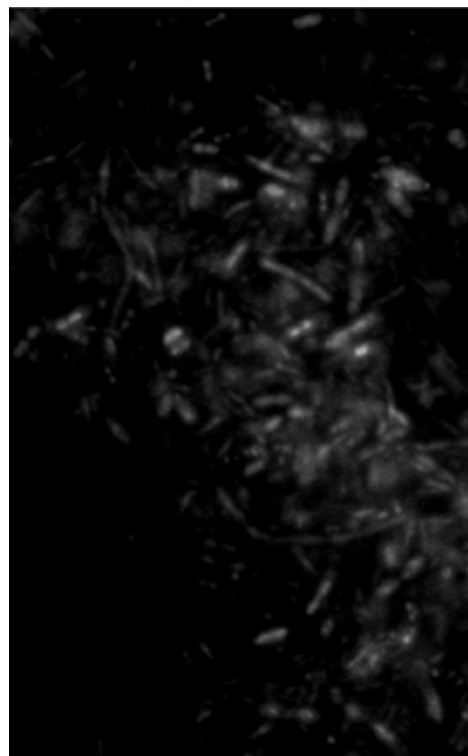

DAPI

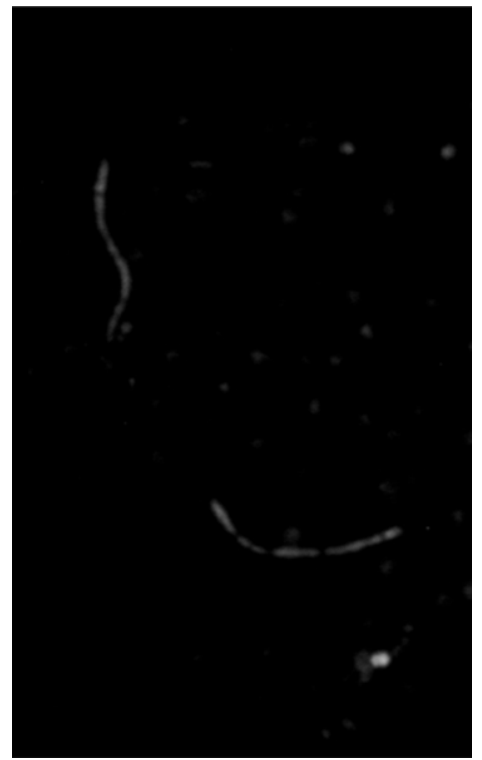

Lacb722

Fig 1 Epifluorescence images of microbial cells (stained with DAPI) and Lactobacillus cells (hybridized with probe Lacb722) in $24 \mathrm{~h}$ static batch culture of human fecal slurry with mannoligosaccharides.

Table 2 Microbial populations in the $24 \mathrm{~h}$ static batch culture fermentations with the various carbon sources

\begin{tabular}{lccccc}
\hline & \multicolumn{5}{c}{ Microbial population $\pm \mathrm{SD}^{*}$} \\
\cline { 2 - 6 } Population & $\begin{array}{c}\text { Stain or } \\
\text { probe }\end{array}$ & Glucose & Sucrose & Glucomannan & Mannoligosaccharides \\
\hline Total microbiota (log10 cells.g g $\left.^{-1}\right)$ & DAPI & $9.43 \pm 0.02^{b}$ & $9.40 \pm 0.03^{a}$ & $9.47 \pm 0.02^{c}$ & $9.47 \pm 0.03^{c}$ \\
Lactobacillus (\%) & Lacb722 & $0.65 \pm 0.59^{a}$ & $2.57 \pm 0.67^{a b}$ & $3.18 \pm 0.88^{b}$ & $10.90 \pm 3.65^{c}$ \\
Bifidobacterium (\%) & Bif164m & $0.89 \pm 0.90^{a}$ & $0.10 \pm 0.22^{a}$ & $2.46 \pm 1.13^{b}$ & $3.28 \pm 1.17^{b}$ \\
Clostridium/Eubacterium group (\%) & Erec482 & $21.14 \pm 5.91^{b}$ & $20.39 \pm 5.56^{b}$ & $17.39 \pm 4.55^{a b}$ & $13.93 \pm 2.02^{a}$ \\
Streptococcus (\%) & Strc493 & $\mathrm{ND}^{* *}$ & $\mathrm{ND}$ & $\mathrm{ND}$ & $\mathrm{ND}$ \\
\hline
\end{tabular}

*SD, standard deviation

$* * \mathrm{ND}$, not detected

high level lactate were detected in sucrose medium and mannoligosaccharides medium, as much of 36.05 and $34.84 \mathrm{mmol} \mathrm{L}^{-1}$, respectively (Table 3 ). In contrast, very low level of lactate was observed in glucomannan medium. The culture cultivated in the presence of glucose showed moderate level of lactate $(24.06 \mathrm{mmol}$ $\left.\mathrm{L}^{-1}\right)$. The highest concentration of acetate $(36.19 \mathrm{mmol}$ $\left.\mathrm{L}^{-1}\right)$ was observed in mannoligosaccharides medium. Glucose medium tend to modulate the microbial community to produce slight acetate in medium. Propionate was detected higher in mannoligosaccharides and glucomannan media $\left(8.54\right.$ and $\left.9.58 \mathrm{mmol} \mathrm{L}^{-1}\right)$ than in other substrates. In general, the total detected
SCFA in medium was observed in mannoligosaccharides medium (79.57 $\mathrm{mmol} \mathrm{L}^{-1}$ ) indicating that mannoligosaccharides was a substance in which intestinal microbiota prefered to use it as digestible substrate (Table 3).

\section{DISCUSSION}

Our data actually support the advantages of mannoligosaccharides as main compound in glucomannan hydrolysate on stimulating intestinal lactobacilli (Table 1, Table 2), in addition, without any significant changes in bifidobacteria and streptococci 


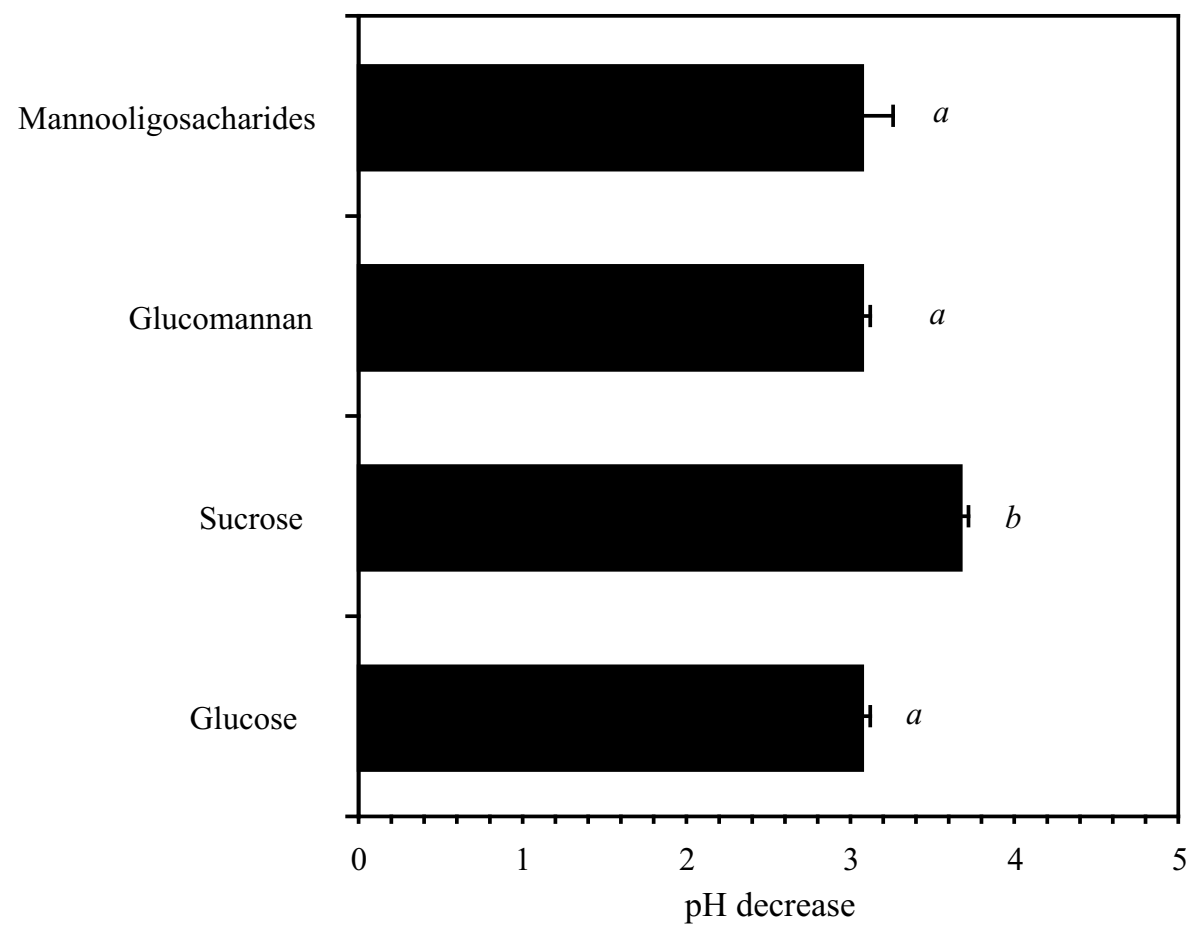

Fig 2 Dicreases in $\mathrm{pH}$ value of the static batch cultures of human fecal slurry during $24 \mathrm{~h}$ fermentation with various carbon sources.

Table 3 SCFA concentration in the $24 \mathrm{~h}$ static batch culture fermentations with the various carbon sources.

\begin{tabular}{|c|c|c|c|c|}
\hline & \multicolumn{4}{|c|}{$\mathrm{SCFA}$ concentration $\left(\mathrm{mmol} \mathrm{L}{ }^{-1}\right) \pm \mathrm{SD}^{*}$} \\
\hline & Glucose & Sucrose & Glucomannan & Mannoligosaccharides \\
\hline Lactate & $24.06 \pm 3.98^{b}$ & $36.05 \pm 3.28^{b}$ & $9.93 \pm 2.80^{a}$ & $34.84 \pm 1.29^{b}$ \\
\hline Acetate & $11.08 \pm 0.72^{a}$ & $17.63 \pm 1.73^{a}$ & $18.15 \pm 2.30^{a}$ & $24.47 \pm 16.57^{a}$ \\
\hline Propionate & $0.48 \pm 0.08^{a}$ & $0.09 \pm 0.13^{a}$ & $9.58 \pm 0.46^{a b}$ & $5.85 \pm 3.79^{b}$ \\
\hline Succinate & $\mathrm{ND}^{* *}$ & ND & ND & ND \\
\hline Total & $35.62 \pm 3.34^{a}$ & $53.76 \pm 5.13^{a}$ & $37.66 \pm 0.95^{a}$ & $65.17 \pm 19.07^{a}$ \\
\hline
\end{tabular}

*SD, standard deviation

**ND, not detected

(Table 2). We pressumed that mannoligosaccharides hydrolysate is likely preferred by lactobacilli rather than glucomannan itself in the term of simple utilization of oligosaccharides. In animal experiment, the increased population of lactobacilli in dog feces due to diet containing mannoligosaccharides was also reported (Swanson et al. 2002). The effects of glucomannan and acid-hydrolyzed mannoligosaccharides of konjac on cecal microbiota in Balb/C mice have been investigated where both glucomannan and mannoligosaccharides were capable of increasing bifidobacteria and oppositely decreasing Clostridium perfringens in mice cecum. In addition, mannoligosaccharides caused increases in fecal total anaerobe counts (Chen et al. 2005). Similar phenomenon was observed where mannoligosaccharides significantly reduced fecal $C$. perfringens and Escherichia coli counts (Elamir et al. 2008). The effect of glucomannan hydrolysates added to the ultra-high temperature milk on the growth of lactic acid bacteria was evaluated (Al-Ghazzewi et al. 2007). The authors also reported that the glucomannan hydrolysates produced with either mannanase or cellulase enzymes were effective growth promoters (carbon sources) of lactic acid bacteria (Al-Ghazzewi and Tester 2012).

Glucomannan is a kind of polysaccharide of the 
glucomannan family. It was composed of $\beta-1,4$ linked D-mannose and D-glucose monomers (Maeda et al. 1980), although the mannose/glucose monomer ratio may vary depending on the original source of glucomannan. There are several enzymes involving in the complete degradation of the glucomannan including $\beta$-mannanase, $\beta$-mannosidase, and $\beta$ glucosidase (Alonso-Sande et al. 2009). Enzyme $\beta$ mannanase catalyzed the random cleavage of $\beta-\mathrm{D}-1,4-$ mannopyranosyl linkages to produce mannobiose and mannotriose. The conversion of glucomannan into ${ }_{D}^{-}$ mannose is by enzyme $\beta$-mannosidase that remove $\beta$ mannose residues from $\beta$-1,4-linked mannoligosaccharides. Specificaly, the degradation by $\beta$-glucosidase occurs only at a terminal glucose unit and stops at terminal oxidized residues or mannose units. The enzyme of $\beta$-mannanase and $\beta$-mannosidase are present in many microorganisms including bacteria harbored in human gut. In addition, the $\beta$-glucosidase genes are widespread among human gut bacteria (Gill et al. 2006). A member of human gut lactic acid bacteria, L. gasseri, encoded twenty kinds of putative glycosyl hydrolases which mostly glucosidases and galactosidases with predicted substrate specificities for a diversity of di- and trisaccharides. The $\beta$-glucosidase of this strain is specific and have no homolog among lactic acid bacteria (Azcarate-Peril et al. 2008). The substrate specifity was suggested to be important key in oligosaccharides utilization by lactobacilli.

Although several constraints of this study have included most detected microbes of intestinal samples are culturable and static culture condition may impact to tolerance against acidic condition where organic acid implicate to reduce the $\mathrm{pH}$ values, this study could explain the direct impact of prebiotic candidate to the growth selected individual strains ( $L$. plantarum and $L$. fermentum). Those strains were previously observed in separate study for reducing the cholesterol in medium after $36 \mathrm{~h}$ incubation (Dinoto et al. unpublished data). Thus, by understanding the suitable substrate, the development synbiotic product with mannoligosaccharides will be interesting aspect in term of functional foods. In mice experiment, konjac glucomannan and the products of partially-hydrolysed konjac glucomannan was compared. Based on culture-dependent method, the total anaerobes and the populations of lactobacilli, and bifidobacteria were higher in partially-hydrolysed konjac glucomannan indicating the preference of those beneficial bacteria on specific digested product of glucomannan. In addition, it was reported also that partially-hydrolysed konjac glucomannan showed better protective effects on fecal water-induced DNA damage as the prebiotic property than did the unhydrolysed konjac glucomannan (Connoly et al. 2010). In conclusion, this study demostrated that mannoligosaccharides synthesized through enzymatic reaction of $A$. muelleri glucomannan have potential properties as prebiotic candidate. The further study could be conducted for clear characterization in order to improve the healthy condition of the host.

\section{ACKNOWLEDGMENT}

This work was supported by the competitive research grant of Indonesian Institute of Sciences. The authors wish to acknowledge the Biotechnology Culture Collection (BTCC) for providing actinomycetes isolate for producing mannanase.

\section{REFERENCES}

Al-Ghazzewi FH, Khanna S, Tester RF, Piggott J. 2007. The potential use of hydrolysed konjac glucomannan as a prebiotic. J Sci Food Agric. 87(9):1758-1766. doi:10.1002/jsfa.2919.

Al-Ghazzewi FH, Tester RF. 2012. Efficacy of cellulase and mannanase hydrolysates of konjac glucomannan to promote the growth of lactic acid bacteria. J Sci Food Agric. 92(11):2394-2396. doi:10.1002/jsfa.5678.

Alonso-Sande M, Teijeiro-Osorio D, Remuñán-López C, Alonso MJ. 2009. Glucomannan, a promising polysaccharide for biopharmaceutical purposes. Eur J Pharm Biopharm. 7(2)2:453-462. doi:10.1016/j.ejpb.2 008.02.005.

Azcarate-Peril MA, Altermann E, Goh YJ, Tallon R, Sanozky-Dawes RB, Pfeiler RA, arah O'Flaherty S, Buck BL, Dobson A, Duong T, Miller MJ, Barrangou R, Klaenhammer TR. 2008. Analysis of the genome sequence of Lactobacillus gasseri ATCC 33323 reveals the molecular basis of an autochthonous intestinal organism. Appl Environ Microbiol. 74(15):4610-4625.

Chen H, Cheng H, Liu Y, Liu S, Wu W. 2006. Konjac acts as a natural laxative by increasing stool bulk and improving colonic ecology in healthy adults. Nutrition. 22(11):1112-1119. doi: 10.1016/j.nut.2006.08.009.

Connolly ML, Lovegrove JA, Tuovy KM. 2010. Konjac glucomannan hydrolysate beneficially modulates bacterial composition and activity within the faecal microbiota. J Funct Foods. 2(3):219-224. doi:10.1016/j .jff.2010.05.001.

Chua M, Baldwin TC, Hocking TJ, Chan K. 2010. Traditional uses and potential health benefits of Amorphophallus konjac K. Koch ex N.E.Br. J Ethnopharm. 128(2):268278. doi:10.1016/j.jep.2010.01.021.

de Man JC, Rogosa M, Sharpe ME. 1960. A medium for the cultivation of lactobacilli. J Appl Bacteriol. 23(1):130135. doi:10.1111/j.1365-2672.1960.tb00188.x. 
Dinoto A, Marques TM, Sakamoto K, Fukiya S, Watanabe J, Ito S, Yokota A (2006a) Population dynamics of Bifidobacterium species in human feces during raffinose administration monitored by fluorescence in situ hybridization-flow cytometry. Appl Environ Microbiol. 72(12):7739-7747. doi:10.1128/AEM.01777-06.

Dinoto A, Suksomcheep A, Ishizuka S, Kimura H, Hanada S, Kamagata Y, Asano K, Tomita F, Yokota A (2006b) Modulation of rat cecal microbiota by administration of raffinose and encapsulated Bifidobacterium breve. Appl Environ Microbiol. 72(1):784-792. doi:10.1128/ AEM.72.1.784-792.2006.

Elamir AA, Tester RF, Al-Ghazzewi FH, Kaal HY, Ghalbon AA, Elmegrahai NA, Piggott JR. 2008. Effects of konjac glucomannan hydrolysates on the gut microflora of mice. Nutr Food Sci. 38(5):422-429. doi: 10.1108/00346650810906930.

Franks AH, Harmsen HJM, Raangs GC, Jansen GJ, Schut F, Welling GW. 1998. Variations of bacterial populations in human feces measured by fluorescent in situ hybridization with group-specific 16S rRNA-targeted oligonucleotide probes. Appl Environ Microbiol. 64(9):3336-3345.

Gill SR, Pop M, DeBoy RT, Eckburg PB, Turnbaugh PJ, Samuel BS, Gordon JI, Relman DA, Fraser-Liggett CM, Nelson KE. 2006. Metagenomic analysis of the human distal gut microbiome. Science 312(5778):1355-1359.

Kay DE. 1973. Root crops. The Tropical Products Institute, London.

Maeda M, Shimahara H, Sugiyama N. 1980. Detailed examination of the branched structure of konjac glucomannan. Agric Biol Chem. 44(2):245-252.

Martino F, Martino E, Morrone F, Carnevali E, Forcone R, Niglio T. 2005. Effect of dietary supplementation with glucomannan on plasma total cholesterol and low density lipoprotein cholesterol in hypercholesterolemic children. Nutr Metab Cardiovasc Dis. 15(3):174-180. doi: 10.1016/j.numecd.2004.04.004.

Olano-Martin E, Mountzouris KC, Gibson GR, Rastall RA. 2000. In vitro fermentability of dextran, oligodextran and maltodextrin by human gut bacteria. Br J Nutr. 83(3):247-255. doi:10.1017/S0007114500000325.

Rossi M, Corradini C, Amaretti A, Nicolini M, Pompei A, Zanoni S, Matteuzzi D. 2005. Fermentation of fructooligosaccharides and inulin by bifidobacteria: A comparative study of pure and fecal cultures. Appl Environ Microbiol. 71(10):6150-6158. doi:10.1128/A EM.71.10.6150-6158.2005.

Rycroft CE, Jones MR, Gibson GR, Rastall RA. 2001. A comparative in vitro evaluation of the fermentation properties of prebiotic oligosaccharides. J Appl Microbiol. 91(5):878-887. doi:10.1046/j.13652672.2001.01446.x.

Sghir A, Antonopoulos D, Mackie RI. 1998. Design and evaluation of a Lactobacillus group-specific ribosomal RNA-targeted hybridization probe and its application to the study of intestinal microecology in pigs. Syst Appl Microbiol. 21(2):291-296. doi:10.1016/S07232020(98)80036-2.

Swanson KS, Grieshop CM, Flickinger EA, Bauer LL, Healy H, Dawson KA, Merchen NR, Fahey GC. 2002. Supplemental fructooligosaccharides and mannoligosaccharides influence immune function, ileal and total tract nutrient digestibilities, microbial populations and concentrations of protein catabolites in the large bowel of dogs. J Nutr. 132(5):980-989.

Titapoka S, Keawsompong S, Haltrich D, Nitisinprasert S. 2008. Selection and characterization of mannanaseproducing bacteria useful for the formation of prebiotic manno-oligosaccharides from copra meal. World J Microbiol Biotechnol. 24(8):1425-1433. doi:10.1007/s 11274-007-9627-9.

Tuohy KM, Rouzaud GCM, Brück WM, Gibson GR. 2005. Modulation of the human gut microflora towards improved health using prebiotics-Assessment of efficacy. Curr Pharm Design. 11(1): 75-90.

Zhang Y, Xie B, Gan X. 2005. Advance in the applications of konjac glucomannan and its derivatives. Carbohydr Polym. 60(1):27-31. doi:10.1016/j.carbpol.2004.11.003. 